\title{
Multidrug-Resistant Epi-Endophytic Bacterial Community in Posidonia Oceanica Seagrass from Mahdia Coastal Seawater as Biomonitoring Factor for Antibiotic Contamination
}

\section{Amel Jebara}

Universite de Monastir

\section{Wafa Hassen}

Université de Monastir: Universite de Monastir

\section{Amira Ouesleti}

Université de Monastir: Universite de Monastir

Lotfi Mabrouk

Université de Gafsa: Universite de Gafsa

\section{Ahlem Jaziri}

Université de Monastir: Universite de Monastir

\section{Guiseppa Di Bella}

University of Messina Faculty of Physical and Natural Sciences: Universita degli Studi di Messina

Hedi Ben Mansour ( $\nabla$ hdbenmansour@gmail.com )

Institut Superieur des Sciences Appliquees et de Technologie de Mahdia https://orcid.org/0000-0001-7936-9828

\section{Research Article}

Keywords: Pollution, Mediterranean coastal ecosystem, Posidonia oceanica, bacterial isolates, antibiotic resistance.

Posted Date: December 22nd, 2021

DOI: https://doi.org/10.21203/rs.3.rs-1181182/v1

License: (c) (i) This work is licensed under a Creative Commons Attribution 4.0 International License. Read Full License 


\section{Abstract}

Faced with the significant disturbances, mainly of anthropogenic origin, which affect the Mediterranean coastal ecosystem, it is necessary to set up rapid diagnostic tools for these disturbances. Posidonia oceanica, which is one of the pillars of this ecosystem, has often been used to assess the state of health of the Mediterranean coastal environment. Despite environmental changes, this plant can accumulate reserves which allow it, during relatively long periods, to keep a stationary phenology. It may also represent important mechanisms for the dissemination of antibiotic resistance genes among pathogenic bacterial populations. The present study aims to determine the multi-drug resistance patterns among isolated and identified epi-endophytic bacterial strains in Posidonia oceanica seagrass collected from Mahdia coastal seawater (Tunisia). 43 isolates were obtained, seven of them were selected and identified. These isolates belonged to the genus Bacillus. Susceptibility patterns of these strains were studied toward commonly used antibiotics in Tunisia. All identified isolates were completely resistant to Aztreonam, Ceftazidime, Trimethoprim, Amoxicillin and Rifampicin.

\section{Introduction}

Human activities have impacted ecosystems for several decades, posing real environmental problems with regard to biodiversity and resources, particularly in the marine environment, the final receptacle for chemical pollutants. Indeed, various disturbances, generally of anthropogenic origin, combine and contribute to weakening the marine ecosystem, mainly at the coasts (Afsa et al., 2020). Antibiotics residue attracts more attention in many countries in the world. Veterinary and human antibiotics residues are continuously introduced into the environment by manufacturing industries, wastewater treatment plant (WWTP) and as well as through the aquaculture development, which can have an impact on the water quality, the ecosystem and the human and animal health (Afsa et al., 2020; Alibi et al., 2021). Several previous studies have been conducted to characterize marine pollutants and monitor their effects on coastal marine ecosystems (Montefalcone, 2009; EL Zrelli et al., 2017; Bonanno et al., 2020; Afsa et al., 2020; Jebara et al., 2021a,b,c; Alibi et al., 2021; Hassen et al., 2021). They also noted that seagrasses are the most organisms used as biomarkers of water quality and health.

Seagrasses are marine clonal angiosperms that evolved from terrestrial monocots about 100 million years ago (Orth et al., 2006; Papenbrock, 2012). This polyphyletic ecological group includes approximately about 60 species that have developed several specific adaptations for marine life (Hartog and Kuo, 2006). Seagrass meadows is one of the most productive aquatic ecosystems and can store up to twice as much carbon as temperate and tropical forests (Garcias-Bonet et al., 2012; Vohník et al., 2015). Furthermore, these Seagrass meadows augment coastal biodiversity and preclude coastal erosion (Garcias-Bonet et al., 2012).

Posidonia oceanica is the dominant seagrass species in the Mediterranean Sea. Posidonia meadows have a remarkable distribution off the Tunisian coast. They cover large areas from North to South (Ben Mustapha and Hattour, 1992; Ben Mustapha and Afli, 2007; Mabrouk, 2012; Ben Brahim, 2012). Several studies have focused on the species of $P$. oceanica (L.) Delile as being an excellent bioindicator for evaluating the quality of the environment of coastal stations (Ferrat et al., 2003; Lafabrie et al., 2007; Serrano et al., 2011; Serrano et al., 2012). Most of these latest studies have shown that $P$. oceanica has the capacity to sequester chemical pollutants from the marine environment and accumulate them in its perennial tissues for several decades (Jebara et al., 2021b). Therefore, $P$. oceanica is a reflector of the ecological state of coastal ecosystems and its storage capacity of geochemical records of the marine environment could be used as an alternative to trace the history of contamination of coastal ecosystems (Tovar-Sánchez et al., 2010). In addition, Posidonia meadows promotes the development of species of economic interest (crustaceans, cephalopods, fish), including microorganisms that play important role in the marine environment (Torta et al., 2015). Many studies have described the diversity of endophytic bacterial communities associated with seagrasses meadows (leaves, rhizomes and roots) and others associated with plant surfaces (epiphytic bacterial community), suggesting their beneficial role in plants (Garcias-Bonet et al., 2012; Vohník et al., 2016; Bibi et al., 2018; Tarquinio et al., 2019; Boontanom and Chantarasiri, 2020). The aim of the present work was to study the bacterial diversity in five coastal seawater samples collected from Mahdia coastal (Tunisia) and to evaluate the antibiotic resistance patterns of isolated bacteria from Posidonia oceanica seagrass. These strains may be considered as bioindicator for biomonitoring the degree of contamination of pollution in Mediterranean seawater.

Page 2/13 


\section{Material And Methods}

\section{Study area and sample collection}

Mahdia coast is one of the most important aquatic ecosystems in Tunisia occupying a very strategic geographic territory with approximately $75 \mathrm{~km}$ of coastline, presenting a predominant fishery, heritage and agricultural wealth. Despite its wealth, the Mahdia coast is subject to several sources of urban and industrial pollution, in addition, the development of fishing activity. To cover the whole of this zone, Posidonia oceanica seagrass and seawater were collected in September 2019 from five sites: (S1) the coastal zone of Mahdia, (S2) the coastal zone of Rejiche, (S3) the coastal zone of Salakta, (S4) the coastal zone of Chebba and (S5) the coastal zone of Mellouleche (Figure 1).

Samples of Posidonia oceanica seagrass (leaves and epiphytes) were collected from each site at $2.5 \mathrm{~m}$ depth by scuba divers and placed in sterile polythene bags. In the same time, one liter of seawater was sampled aseptically from each site by Niskin bottles in previously sterilized glass bottles. The collected samples were immediately transported to the laboratory and kept at $4^{\circ} \mathrm{C}$ until analysis (within $24 \mathrm{~h}$ after collection).

\section{Culture-independent approach: DGGE analysis}

\subsection{Total DNA extraction}

For studies of bacterial community structure in Mahdia coast, 1 liter of each seawater sample was filtered through a sterile cellulose nitrate membrane with a pore size of $0.2 \mu \mathrm{m}$ ( $47 \mathrm{~mm}$ diameter). Total DNA was extracted as described by Yoshida et al., (2008) with slight modifications. Briefly, $1.8 \mathrm{~mL}$ of lysis buffer and $90 \mu \mathrm{L}$ of freshly made lysozyme was added to the filter. The filter was incubated for $30 \mathrm{~min}$ at $37^{\circ} \mathrm{C}$, and then $50 \mu \mathrm{L}$ of proteinase $\mathrm{K}(20 \mathrm{mg} / \mathrm{mL})$ and $210 \mu \mathrm{L}$ of sodium dodecyl sulfate solution (10\%) were added. After incubation for $2 \mathrm{~h}$ at $55^{\circ} \mathrm{C}$, the sample was treated with phenol/chloroform/isoamyl alcohol (25:24:1). After centrifugation, the aqueous phase was mixed with chloroform/isoamyl alcohol (24:1) and the resulting supernatant containing the DNA was precipitated with isopropanol at $-20^{\circ} \mathrm{C}$. Finally, the purified DNA was washed with ethanol and dissolved in TE buffer. To check the molecular size and DNA concentration, the obtained DNA was analyzed by agarose gel electrophoresis.

\subsection{PCR Amplification}

Polymerase chain reaction (PCR) amplification targeting the V3-V5 hypervariable region of the 16S rRNA gene was carried out with universal primers specific to the bacteria domain: 907R 3'-CCGTCAATTCCTTTGATGTTT-5' and 357F 3'-

TACGGGAGGCAGCAG-5' with a 5'-end GC-clamp (Hassen et al., 2020). The reaction mixture consisted of 1x PCR buffer, $2.5 \mathrm{mM}$ $\mathrm{MgCl}_{2}, 0.12 \mathrm{mM}$ dNTPs, $0.3 \mathrm{mM}$ of each primer, $1 \mathrm{U}$ of Taq polymerase and $1 \mu \mathrm{l}$ of appropriately diluted template DNA in a final volume of $30 \mu \mathrm{l}$. DNA amplification was performed under the following conditions: $94^{\circ} \mathrm{C}$ for $4 \mathrm{~min} ; 10$ cycles of $94^{\circ} \mathrm{C}$ for $30 \mathrm{~s}$, $61^{\circ} \mathrm{C}$ for $1 \mathrm{~min}$, and $72^{\circ} \mathrm{C}$ for $1 \mathrm{~min}$; followed by further 20 cycles of $94^{\circ} \mathrm{C}$ for $30 \mathrm{~s}, 56^{\circ} \mathrm{C}$ for $1 \mathrm{~min}$, and $72^{\circ} \mathrm{C}$ for 1 min and finally $72^{\circ} \mathrm{C}$ for $10 \mathrm{~min}$. The expected DNA fragments of $630 \mathrm{bp}$ were verified on $1.5 \%$ agarose gel.

\subsection{Denaturing gradient gel electrophoresis}

PCR products were resolved on $7 \%(\mathrm{w} / \mathrm{v})$ polyacrylamide gel in $1 \times \mathrm{TAE}$ with a linear gradient of denaturant urea ranging from 40 to $60 \%$ (Hassen et al., 2021). The electrophoresis was run at a constant voltage of $90 \mathrm{~V}$ for $20 \mathrm{~h}$ at $60^{\circ} \mathrm{C}$ in $1 \times$ TAE running buffer. The gel was then stained for $30 \mathrm{~min}$ in a $5 \mathrm{mg} / \mathrm{L}$ solution of ethidium bromide, washed with sterile distilled water and immediately photographed under UV transillumination table.

DGGE profiles were exploited to create matrices indicating the presence or absence of bands, and a dendrogram was built by the MVSP software (MultiVariate Statistical Package), which uses the algorithm Unweighted Pair Group Method with Arithmetic Mean (UPGMA) and the Jaccard's coefficient. The Simpson's Diversity Index (D) and R richness index were determined. The band patterns of DGGE gel were further examined with an image analyzing system by using Image $J$ software (version 1.46) and Principal component analysis (PCA) was produced using Microsoft Excel XLSTAT software (version 2021.2) which allows the conversion of the bands density and migration into numerical values. 


\section{3- Isolation of epi-endophytic bacteria from Posidonia oceanica seagrass}

Epi-endophytic bacteria were isolated from leaves and epiphytes of Posidonia oceanica seagrass. The collected leaves were subjected to a surface-sterilization protocol adapted from Garcias-Bonet et al., (2012). Briefly, the leaves samples were rinsed with distilled water and then disinfected superficially in $70 \%$ ethanol for 1 min. After, they were sterilized for 4 minutes in sodium hypochlorite (2.5\%) and finally washed ten times with sterile distilled water. Afterward, they were aseptically fragmented into smaller pieces and crushed with aqueous solution $(0.9 \% \mathrm{NaCl})$ using a homogenizer. For epiphytes, they were scraped from two faces of the surface of Posidonia oceanica leaves and then recovered in sterile Eppendorf tubes with aqueous solution.

One milliliter of each samples (tissue homogenate or epiphytes) was placed in $250 \mathrm{~mL}$ Erlenmeyer flask containing the following enrichment marine media: $\mathrm{H}_{3} \mathrm{BO}_{3}, 0.022 \mathrm{~g} / \mathrm{L} ; \mathrm{NH}_{4} \mathrm{NO}_{3}, 0.0016 \mathrm{~g} / \mathrm{L} ; \mathrm{CaCl}_{2}, 1.8 \mathrm{~g} / \mathrm{L} ; \mathrm{SrCl}_{2}, 0.034 \mathrm{~g} / \mathrm{L} ;$ Yeast Extract, $1 \mathrm{~g} / \mathrm{L} ; \mathrm{C}_{6} \mathrm{H}_{5} \mathrm{FeO}_{7}$, $0.1 \mathrm{~g} / \mathrm{L} ; \mathrm{MgCl}_{2}, 8.8 \mathrm{~g} / \mathrm{L} ;$ Peptone, $5 \mathrm{~g} / \mathrm{L} ; \mathrm{KBr}, 0.08 \mathrm{~g} / \mathrm{L} ; \mathrm{KCl}, 0.55 \mathrm{~g} / \mathrm{L} ; \mathrm{NaCl}, 19.4 \mathrm{~g} / \mathrm{L} ; \mathrm{NaF}, 0.0024 \mathrm{~g} / \mathrm{L} ; \mathrm{NaHCOQ}, 0.16 \mathrm{~g} / \mathrm{L} ; \mathrm{Na}_{2} \mathrm{HPO}_{4}$, $0.008 \mathrm{~g} / \mathrm{L} ; \mathrm{Na}_{2} \mathrm{SiO}_{3}, 0.004 \mathrm{~g} / \mathrm{L} ; \mathrm{Na}_{2} \mathrm{SO}_{4}, 3.24 \mathrm{~g} / \mathrm{L} ; \mathrm{pH}: 7.6 \pm 0.2$, and incubated at $25^{\circ} \mathrm{C}$ on a rotary shaker at $120 \mathrm{rpm}$ for 3 days. Isolation of pure bacterial strains from the enrichment cultures was performed by using serial dilution $\left(10^{-1}-10^{-8}\right)$ onto marine agar plates. The plates were subsequently incubated at $25^{\circ} \mathrm{C}$ for 5 days. Colonies were counted and expressed as Colony-Forming Unit (CFU) per $\mathrm{mL}$.

The pure colonies were selected according to their morphology characteristics (color, size, shape), transferred to the same marine media and purified by repeated streaking to obtain pure cultures. All bacterial isolates were characterized by determining their Gram reaction, catalase and oxidase activity. The bacterial isolates were stored as $25 \%$ glycerol stocks at $-80^{\circ} \mathrm{C}$.

\section{4- Antibiotic susceptibility testing}

Antimicrobial susceptibility testing was performed on 43 isolates by the disk diffusion method on Mueller Hinton agar plates (Difco, Bectone Dickinson, Sparks, MD) according to the National Committee for Clinical Laboratory Standards guidelines (CLSI, 2017). Twelve antimicrobial agents were tested (Table 1).

\section{5- Taxonomic identification of multi-antibiotic resistant epi-endophytic bacteria}

Genomic DNA was extracted from each of the seven selected multi-antibiotic resistant isolates by sodium dodecyl sulphate (SDS)-proteinase $\mathrm{K}$ treatment according to Hassen et al., (2018), followed by the amplification of 16S-23S rRNA Intergenic Transcribed Spacer-PCR (ITS-PCR) using ITS-F (3'-GTCGTAACAAGGTAGCCGTA-5') and ITS-R (3'-CTACGGCTACCTTGTTACGA-5') primers as previously described by (Hassen et al., 2018).

16S rRNA amplification was carried out by using the universal primers S-D-Bact-0008-a-S-20 (3'-CTACGGCTACCTTGTTACGA-5') and S-D-Bact-1495-a-S-20 (3'AGATTTGATCCTGGCTCAG-5'). The PCR master-mix (30 $\mu \mathrm{L})$ contained $22.86 \mu \mathrm{L}$ PCR-water, $2 \mu \mathrm{L}$ Taq buffer (10x), $0.24 \mu \mathrm{L}$ dNTP-Mix (25 mM, each), $2.5 \mu \mathrm{L} \mathrm{MgCl} 2(25 \mathrm{mM}), 0.2 \mu \mathrm{L} \mathrm{Taq}(1 \mathrm{U} / \mu \mathrm{L}), 2 \times 0.6 \mu \mathrm{L}$ of the respective primers $(25 \mu \mathrm{mol} / \mu \mathrm{L})$ and $1 \mu \mathrm{L}$ of appropriately diluted template DNA in a final volume of $50 \mu \mathrm{L}$. The PCR program included an initial denaturing step at $94^{\circ} \mathrm{C}$ for $3 \mathrm{~min}, 30$ cycles of $94^{\circ} \mathrm{C}$ for $45 \mathrm{~s}, 55^{\circ} \mathrm{C}$ for $1 \mathrm{~min}$, and $72^{\circ} \mathrm{C}$ for $2 \mathrm{~min}$, and a final extension at $72{ }^{\circ} \mathrm{C}$ for 7 min (Hassen et al., 2020). All the PCR products were confirmed by electrophoresis on $2 \%$ agarose gels and stained for 20 min in $0.5 \mathrm{mg} / \mathrm{L}$ ethidium bromide solution.

ITS profiles were visually analyzed to group together the bacterial isolates exhibiting the same band pattern. The amplified $16 \mathrm{~S}$ rRNA fragments were sequenced and analyzed by comparison with sequences available at the National Centre for Biotechnology Information (NCBI) database (http://www.ncbi.nlm.nih.gov) using the BLAST program as described by Hassen et al., (2018). A phylogenetic dendrogram was constructed using the neighbor joining method and tree topology was evaluated by bootstrap analysis of 1000 data sets using MEGA 6 (Kumar et al., 2008). The partial 16S rRNA gene sequences of each isolate were submitted to NCBI GenBank database under the accession numbers MZ350537 to MZ350543.

\section{Results And Discussion}

\section{1-DGGE Analysis}

Page $4 / 13$ 
To investigate the diversity and the dynamics of the dominating microbial communities, samples from five coastal seawater sites of Mahdia were analyzed by denaturing gradient gel electrophoresis (DGGE), which is one of the most commonly used methods among the culture-independent fingerprinting techniques (Li et al., 2010). Moreover, DGGE analysis of 16S rRNA gene was applied to present an overview of culturable and unculturable bacterial assemblages. 16S rRNA fragments, obtained by targeting of the variable V3-V5 region by the PCR-DGGE, were separated on a polyacrylamide denaturing gel (Figure 2). Samples from all sites were analyzed in triplicate. Visual analysis of DGGE band profiles highlighted a large variability in bacterial community structure of all the samples. A remarkable similarity was noted between the three replicates of each site. We detected several bands with variable intensities and migration distances. Some of the bands were specific to a given site, while, other bands were found to be common to more than one sample. The obtained profiles showing a difference in migration, which allowed the bands to be divided into three migration levels: short migration bands (non-rich bands in GC), medium migration bands (moderately rich in GC) and long migration bands corresponding to high GC content sequences (Figure 2). A very similar variation was revealed in all profiles of different seawater coastal, which gave us a general idea of the abundance of the same bacterial community between the different sites.

Similarly to this study, DGGE was used by Schäfer et al., (2001) in Mediterranean Seawater treated with nutrients and they have shown its effectiveness in determining bacterial genetic diversity and activity in each treatment. However, the threshold for detection of a microbial communities by PCR-DGGE is approximately 1 to $2 \%$, which represents the dominant species (Mehri et al., 2014).

The PCR-DGGE gel profiles were also used to evaluate the bacterial community richness and biodiversity indexes of seawater coastal samples obtained from different sites in Mahdia city, Tunisia. The species richness index $(R)$ determined was highest for DGGE profiles of Mahdia and Salakta seawater coastal samples $(R=9)$, thus exhibiting the highest number of bands/bacterial species than those of Melloulech seawater coastal sample $(R=8)$; Rejiche seawater coastal sample $(R=7)$ and of Chebba seawater coastal sample (R=3) (Figure 2). Bacterial diversity index (D) calculated on the basis of number of bands existing on polyacrylamide gel was also highest for Mahdia and Salakta seawater coastal samples $(D=0.889)$ with the lowest being Chebba seawater coastal sample $(0.667<\mathrm{D}<0.75)$ (Figure 2). Diverse activities in seawater such as industrial, agricultural and port activities could be responsible for this observation. Similar works has mentioned that pollution could affect the structure of the bacterial community (Campbell et al., 2015; Moreno-Espíndola et al., 2018; Tamburini et al., 2020).

Similarity and variation among DGGE gel patterns of the various coastal seawater sites were also established based on analysis of Jaccard's coefficient with the UPGMA algorithm (Figure 3). The cluster analysis showed a high similarity above $90 \%$, indicating a stable community within S1 (Mahdia seawater coastal site), S2 (Rejiche seawater coastal site), S3 (Salakta seawater coastal site) and S5 (Melloulech seawater coastal site). Furthermore, Chebba seawater coastal site present only $24 \%$ of diversity with other sites.

The principal component analysis (PCA) based on the relative intensities of bands in DGGE profiles provided further information about the microbial community structure existed in five seawater coastal sites (Figure 4). The PCA analysis results confirmed the differences observed visually by showing a variation of $71.34 \%$ and $12.38 \%$ according to the first and second principal axes, respectively. All seawater coastal samples (with three replicates of each site) appeared to be randomly distributed and were relatively adjacent.

However, we could see four groups: the first group of seawater coastal samples (S1-3, S2-1, S2-3 and s3-2) distributed on the left side, according to the negative values of the first principal axis F1 and positive values of the secondary axis F2. The second group is represented by the samples S3-1 S4-2 S4-3 S5-1 and the third group distributed on the right side that contained the samples S1-2, S2-2, S3-3, S4-1, S5-2 and S5-3. The last group could be distinguished from the other samples, is the S1-1 sample which corresponds to the one of three replicates samples of Mahdia seawater coastal site. These results indicated that the bacterial community structure was variable even in replicates from the same site (Figure 4). These observed community variations could be related to the environmental pollution in each coastal zone of Mahdia due to their high rate of urbanization, the discharges of poorly treated wastewater and the excessive use of antibiotics in aquaculture as described by Jebara et al., $(2021 a, b, c)$. Other studies focused on the relationship between the physicochemical factors of the aquatic environment and the 
composition / abundance / diversity of the bacterial communities (Chiriac et al., 2017; Núñez Salazar et al., 2020). Other studies have also reported the decrease of microbial diversity in heavily polluted waters (Kochling et al., 2017; Paruch et al., 2019).

\section{2- Isolation and selection of multi-antibiotic resistant epi-endophytic bacteria}

Posidonia oceanica leaves and their epiphytes, collected from different seawater coastal sites, were enumerated by cultivating on marine agar media. The obtained results showed that the highest levels of cultivable bacteria in the epiphytes and leaves of Posidonia oceanica were detected in Rejiche seawater coastal sample (Table 2). In addition, we have noticed that the count of cultivable bacteria is higher in the epiphytes of Posidonia oceanica than in the Posidonia leaves recovered from Rejiche seawater coastal sample $\left(2.7010^{10}, 2.3210^{10}\right)$, Salakta seawater coastal sample $\left(5.9510^{9}, 3.7210^{9}\right)$ and Melloulech seawater coastal sample $\left(5.2710^{8}, 9.1410^{7}\right)$. These results confirm that epiphytes and Posidonia leaves are considered to be a favorable matrix for bacterial accumulation and development (Borowitzka et al., 2006). In accordance with these results, Tarquinio and colleagues (2019) has also observed a high population density of epi- and endophytic bacteria associated with Posidonia oceanica seagrass. Furthermore, they have indicated that the presence of a different set of microorganisms can have a beneficial role for plant growth, health and productivity (Tarquinio et al., 2019). Fahimipour et al., (2017) showed that bacterial composition of leaves seagrass was highly similar to the surrounding seawater communities. However, they also found contrasting results related to the seagrass roots communities whereby bacterial composition of roots differed from sediment communities.

As mentioned in previous studies, increased consumption of antibiotics contributes to an increase in environmental waste (Polianciuc et al., 2020; Carvalho and Santos, 2016). Seawater is often contaminated with drug residues (Afsa et al., 2020). This contamination encouraged the spread of resistance and even of multi-resistant bacteria (Alibi et al., 2021). A collection of 43 strains was obtained including 21 strains recovered from the epiphytes of Posidonia oceanica and 22 strains from samples of Posidonia leaves. The susceptibility of epi- and endophytic bacterial isolates to 12 antimicrobial agents is shown in Figure 5. A high level of resistance was detected to Aztreonam (72.1\%) and Ceftazidime (60.5\%). A medium level of resistance was observed to Amoxicillin (56\%), Rifampicin (51.2\%), Trimethoprim (44.2\%), Cefotaxime (35\%) and Chloramphenicol (30.2\%). Lower levels were detected to Azithromycin (7\%), Ciprofloxacin (5\%) and to Amikacin (2.3\%). All the studied isolates showed susceptibility to Imipenem and Tetracycline. An antibiotic multi-resistance phenotype was observed. Seven dominated multi-resistance profiles were detected for all the epi- and endophytic bacterial isolates against to 6 families of antibiotics ( $\beta$-lactams, Phenicol, Macrolide, Sulphonamides, Rifamycin and Quinolones) (Table 3). The ecological justification of antibiotic resistance is the adaptation of bacteria in the polluted environment. Bacteria in these polluted aquatic matrices share or exchange transferable elements of DNA with other bacteria, this can occur between different bacterial species (Tahrani et al., 2017).

These multi-antibiotic resistant epi-endophytic bacterial strains were identified by amplification of the ribosomal intergenic transcribed spacer between the $16 \mathrm{~S}$ and the $23 \mathrm{~S}$ rRNA genes (ITS-PCR) and by $16 \mathrm{~S}$ rRNA sequencing. ITS-PCR fingerprinting was applied to assess bacterial diversity of the selected isolates. The ITS profiles showed reproducible patterns consisting of 1 to 7 bands with sizes ranging from 200 to about 400 bp (Figure 6). Four different ITS haplotypes were produced. H1 was represented by one isolate (S1-L1) and composed by 4 reproducible bands (250, 290, 310 and 350 bp). The other ITS profiles were found in two isolates. Partial 16S rRNA gene sequencing was carried out for these 7 isolates and was analyzed by BLAST algorithm (Table 3). Phylogenetic analysis revealed that the selected isolates were assigned to the phylum Firmicutes with low $\mathrm{G}+\mathrm{C} \%$ content gram positive and represented by Bacillus genus (Figure 7), exhibiting 98-100\% of identity to published species sequences. These strains were classified in five spices including $B$. paranthracis (S1-L1), B. wiedmannii (S2-E2; S3-E1; S3-L3), B. oceanisediminis (S3-E2), B. firmus (S4-L7), and B. paramycoides (S5-L13). The high detection of the genus Bacillus in marine niches was in agreement with other studies, Ettoumi et al., (2013) showed that $68 \%$ of marine isolates from the Mediterranean Sea were clustered with B. subtilis, B. licheniformis, B. pumilus and B. cereus. Similarly, Ki et al., (2009) described the identification of thirteen marine Bacillus genotypes, including the following species: $B$. aquaemaris. B. badius, $B$. cereus, $B$. firmus, B. halmapalus, B. hwajinpoensis, B. litoralis, B. sporothermodurans, B. vietnamensis, and Bacillus sp.. Several previous studies also reported that the bacterial diversity in different seagrass parts (leaves, roots and epiphytes) showed predominant bacterial phyla belonging to Actinobacteria, Bacteroidetes, Proteobacteria and Firmicutes and this latter represented specially by Bacillus genus (Nugraheni et al., 2010; Wahjono et al., 2015; Mishra and Mohanraju, 2018; Tarquinio et al., 2019; Boontanom and Chantarasiri, 2020). Studies reported that epi- and endophytic bacterium play an important role in plant growth, health and

Page 6/13 
ecological function (Liu et al., 2017; Bibi et al., 2018) and demonstrated that epiphytic bacteria colonizing the seagrass surface must be able to resist interactions with the host defences processes and competition with other microorganisms (Boontanom and Chantarasiri, 2020).

\section{Conclusion}

Only a few studies focused on bacterial community of Posidonia oceanica seagrass. Here, we studied the epi-endophytic bacterial community of Mahdia coast focusing on multi-resistant bacteria to antibiotics as bio-indicators of pollution. The seawater coastal sites revealed a high bacterial diversity assessed by DGGE approach. From the 43 epi-endophytic bacterial strains isolated from Posidonia leaves and their epiphytes, seven strains were the most dominant multi-resistance profiles. These selected isolates were subjected to identification, characterization and phylogenetic analysis. Firmicute phylum was the single bacterial group distinguished and represented by Bacillus genus. This collection may be considered as bioindicator for biomonitoring the degree of contamination of pollution in Mediterranean seawater.

\section{Declarations}

\section{Acknowledgement}

This work was supported by the UR Analysis and Process Applied to the Environment APAE (Mahdia, Tunisia) and by the Tunisian Ministry of Higher Education and Scientific Research

\section{Authors' Contributions}

WH and HBM conceived and designed the experiments. AJ and WH carried out the functional experiments, analyzed the data and wrote the manuscript. WH, LM, GDB and HBM revised the manuscript.

\section{Ethics approval and consent to participate}

This manuscript does not report data collected from humans or animals.

\section{Consent to Publish}

Not applicable.

\section{Availability of data and materials}

Not applicable.

\section{Funding}

None

\section{Conflict of interest}

The authors declare that they have no conflict of interest regarding the publication of this article.

\section{References}

1. Afsa, S., Hamden, K., Martin, P. A. L., \& Mansour, H. B. (2020). Occurrence of 40 pharmaceutically active compounds in hospital and urban wastewaters and their contribution to Mahdia coastal seawater contamination. Environmental Science and Pollution Research, 27(2), 1941-1955.

2. Alibi S, Beltifa A, Hassen W, Jaziri A, Soussia L, Zbidi F, Ben Mansour H. Coastal Surveillance and Water Quality monitoring in the Rejiche Sea-Tunisia. Water Environ Res. 2021 Apr 16. doi: 10.1002/wer.1573. Epub ahead of print. PMID: 33864319. 
3. Ben Brahim, M. (2012). The marine magnoliophyta Posidonia oceanica Delile: structure, vitality, epiphytism and bioindication in the eastern and south-eastern regions of Tunisia. PhD manuscript. Faculty of Sciences of Sfax: 247. (in French)

4. Ben Mustapha, K., \& Hattour, A. (1992). The Posidonia meadows of the Tunisian coast: 1. The Gulf of Hammamet. Marine Science and Technology, 2: 1-42. (in French)

5. Bibi, F., Naseer, M. I., Hassan, A. M., Yasir, M., Al-Ghamdi, A. A. K., \& Azhar, E. I. (2018). Diversity and antagonistic potential of bacteria isolated from marine grass Halodule uninervis. 3 Biotech, 8(1), 1-8.

6. Bonanno, G., Veneziano, V., \& Orlando-Bonaca, M. (2020). Comparative assessment of trace element accumulation and biomonitoring in seaweed Ulva lactuca and seagrass Posidonia oceanica. Science of The Total Environment, 718, 137413.

7. Boontanom, P., \& Chantarasiri, A. (2020). Diversity of culturable epiphytic bacteria isolated from seagrass (Halodule uninervis) in Thailand and their preliminary antibacterial activity. Biodiversitas Journal of Biological Diversity, 21(7).

8. Borowitzka M.A., Lavery P., Keulen M. (2006) Epiphytes of seagrasses. In: Larkum A.W.D., Orth R.J., Duarte C.M. (Eds), Seagrasses: Biology, Ecology and Conservation. Springer, Dordrecht: 441-461.

9. Campbell AM, Fleisher J, Sinigalliano C, White JR, Lopez JV. Dynamics of marine bacterial community diversity of the coastal waters of the reefs, inlets, and wastewater outfalls of southeast Florida. Microbiologyopen. 2015;4(3):390-408

10. Carvalho IT, Santos L. Antibiotics in the aquatic environments: A review of the European scenario. Environ Int. 2016 Sep;94:736-757. doi: 10.1016/j.envint.2016.06.025. Epub 2016 Jul 15. PMID: 27425630.

11. Chiriac, C. M., Szekeres, E., Rudi, K., Baricz, A., Hegedus, A., Dragoş, N., \& Coman, C. (2017). Differences in temperature and water chemistry shape distinct diversity patterns in thermophilic microbial communities. Applied and environmental microbiology, 83(21), e01363-17.

12. CLSI, (2017). Performance Standards for Antimicrobial Susceptibility Testing. CLSI Supplement M100. 27th ed. Wayne, PA: Clinical and Laboratory Standards Institute.

13. Den Hartog, C., \& Kuo, J. (2007). Taxonomy and biogeography of seagrasses. In Seagrasses: biology, ecologyand conservation (pp. 1-23). Springer, Dordrecht.

14. El Zrelli, R., Courjault-Radé, P., Rabaoui, L., Daghbouj, N., Mansour, L., Balti, R., ... \& Bejaoui, N. (2017). Biomonitoring of coastal pollution in the Gulf of Gabes (SE, Tunisia): use of Posidonia oceanica seagrass as a bioindicator and its mat as an archive of coastal metallic contamination. Environmental Science and Pollution Research, 24(28), 22214-22225.

15. Ettoumi, B., Guesmi, A., Brusetti, L., Borin, S., Najjari, A., Boudabous, A., \& Cherif, A. (2013). Microdiversity of deep-sea Bacillales isolated from Tyrrhenian sea sediments as revealed by ARISA, 16S rRNA gene sequencing and BOX-PCR fingerprinting. Microbes and environments, ME13013.

16. Fahimipour, A. K., Kardish, M. R., Lang, J. M., Green, J. L., Eisen, J. A., \& Stachowicz, J. J. (2017). Global-scale structure of the eelgrass microbiome. Applied and Environmental Microbiology, 83(12), e03391-16.

17. Ferrat, L., Gnassia-Barelli, M., Pergent-Martini, C., \& Romeo, M. (2003). Mercury and non-protein thiol compounds in the seagrass Posidonia oceanica. Comparative Biochemistry and Physiology Part C: Toxicology \& Pharmacology, 134(1), 147155.

18. Garcias-Bonet, N., Arrieta, J. M., de Santana, C. N., Duarte, C. M., \& Marbà, N. (2012). Endophytic bacterial community of a Mediterranean marine angiosperm (Posidonia oceanica). Frontiers in Microbiology, 3, 342.

19. Hassen, W. (2020). Biodegradation of pesticides used in agricultural soils. European University Edition 2020; ISBN: 978-6139-53921-5 (in French).

20. Hassen, W., Alibi, S., \& Ben Mansour, H. (2021). Assessment of the physico-chemical and microbiol pollution of wastewater and seawater collected from five Mediterranean countries. Arabian Journal of Scientific Research, 1.6.

21. Hassen, W., Neifar, M., Cherif, H., Mahjoubi, M., Souissi, Y., Raddadi, N., ... \& Cherif, A. (2018). Assessment of genetic diversity and bioremediation potential of pseudomonads isolated from pesticide-contaminated artichoke farm soils. 3 Biotech, 8(6), 114.

22. Jebara, A., Albergamo, A., Rando, R., Potortì, A. G., Turco, V. L., Mansour, H. B., \& Di Bella, G. (2021a). Phthalates and nonphthalate plasticizers in Tunisian marine samples: Occurrence, spatial distribution and seasonal variation. Marine Pollution Bulletin, 163, 111967. 
23. Jebara, A., Lo Turco, V., Faggio, C., Licata, P., Nava, V., Potortì, A. G., ... \& Di Bella, G. (2021c). Monitoring of Environmental Hg Occurrence in Tunisian Coastal Areas. International Journal of Environmental Research and Public Health, 18(10), 5202.

24. Jebara, A., Turco, V. L., Potortì, A. G., Bartolomeo, G., Mansour, H. B., \& Di Bella, G. (2021b). Organic pollutants in marine samples from Tunisian coast: Occurrence and associated human health risks. Environmental Pollution, 271, 116266.

25. Ki, J. S., Zhang, W., \& Qian, P. Y. (2009). Discovery of marine Bacillus species by 16 S rRNA and rpoB comparisons and their usefulness for species identification. Journal of microbiological methods, 77(1), 48-57.

26. Köchling, T., Sanz, J. L., Galdino, L., Florencio, L., \& Kato, M. T. (2017). Impact of pollution on the microbial diversity of a tropical river in an urbanized region of northeastern Brazil. Int Microbiol, 20(1), 11-24.

27. Kumar, S., Nei, M., Dudley, J., \& Tamura, K. (2008). MEGA: a biologist-centric software for evolutionary analysis of DNA and protein sequences. Briefings in bioinformatics, 9(4), 299-306.

28. Kusmita, L., Nugraheni, S. A., \& Nuryadi, H. (2019). Characterization of cartenoid pigments from Sargassum polycystum and its associated bacteria. Pakistan Journal of Biotechnology, 16(4), 219-226.

29. Lafabrie, C., Pergent, G., Kantin, R., Pergent-Martini, C., \& Gonzalez, J. L. (2007). Trace metals assessment in water, sediment, mussel and seagrass species-validation of the use of Posidonia oceanica as a metal biomonitor. Chemosphere, 68(11), 2033-2039.

30. Li, Q., Zhang, Y., Juck, D., Fortin, N., Greer, C. W., \& Tang, Q. (2010). Phylogenetic analysis of bacterial communities in the shrimp and sea cucumber aquaculture environment in northern China by culturing and PCR-DGGE. Aquaculture international, 18(6), 977-990.

31. Liu, H., Carvalhais, L. C., Crawford, M., Singh, E., Dennis, P. G., Pieterse, C. M., \& Schenk, P. M. (2017). Inner plant values: diversity, colonization and benefits from endophytic bacteria. Frontiers in microbiology, 8, 2552.

32. Mabrouk, L. (2012). Descriptive and analytical study of Posidonia oceanica (L.) Delile meadows on the coasts of the Mahdia region (East of Tunisia): dynamics, spatial and temporal distribution, epiphytisms of leaves and rhizomes and bioindication. PhD manuscript. Faculty of Sciences of Sfax: 282. (in French)

33. Mehri, I., Turki, Y., Chérif, H., Khessairi, A., Hassen, A., \& Gtari, M. (2014). Influence of biological treatment and ultraviolet disinfection system on Pseudomonas spp. diversity in wastewater as assessed by denaturing gradient gel electrophoresis. CLEAN-Soil, Air, Water, 42(5), 578-585.

34. Mishra, A. K., \& Mohanraju, R. (2018). Epiphytic bacterial communities in seagrass meadows of oligotrophic waters of Andaman Sea. Open Access Library Journal, 5(3), 1-12.

35. Montefalcone, M. (2009). Ecosystem health assessment using the Mediterranean seagrass Posidonia oceanica: a review. Ecological indicators, 9(4), 595-604.

36. Moreno-Espíndola, I. P., Ferrara-Guerrero, M. J., Luna-Guido, M. L., Ramírez-Villanueva, D. A., León-Lorenzana, D., Arit, S., ... \& Dendooven, L. (2018). The bacterial community structure and microbial activity in a traditional organic milpa farming system under different soil moisture conditions. Frontiers in microbiology, 9, 2737.

37. Mustapha, K. B., \& Afli, A. Some features of Tunisia's marine biodiversity. Report of the MedSudMed Expert Consultation on Marine Protected Areas and Fisheries Management, 32. (in French)

38. Núñez Salazar, R., Aguirre, C., Soto, J., Salinas, P., Salinas, C., Prieto, H., \& Paneque, M. (2020). Physicochemical parameters affecting the distribution and diversity of the water column microbial community in the high-altitude Andean lake system of La Brava and La Punta. Microorganisms, 8(8), 1181.

39. Orth, R. J., Carruthers, T. J., Dennison, W. C., Duarte, C. M., Fourqurean, J. W., Heck, K. L., ... \& Williams, S. L. (2006). A global crisis for seagrass ecosystems. Bioscience, 56(12), 987-996.

40. Papenbrock, J. (2012). Highlights in seagrasses' phylogeny, physiology, and metabolism: what makes them special?. International Scholarly Research Notices, 2012.

41. Paruch, L., Paruch, A. M., Eiken, H. G., \& Sørheim, R. (2019). Faecal pollution affects abundance and diversity of aquatic microbial community in anthropo-zoogenically influenced lotic ecosystems. Scientific reports, 9(1), 1-13.

42. Polianciuc, S. I., Gurzău, A. E., Kiss, B., Ştefan, M. G., \& Loghin, F. (2020). Antibiotics in the environment: causes and consequences. Medicine and pharmacy reports, 93(3), 231-240.

Page 9/13 
43. Schäfer, H., Bernard, L., Courties, C., Lebaron, P., Servais, P., Pukall, R., ... \& Muyzer, G. (2001). Microbial community dynamics in Mediterranean nutrient-enriched seawater mesocosms: changes in the genetic diversity of bacterial populations. FEMS microbiology ecology, 34(3), 243-253.

44. Serrano, O., Mateo, M. A., \& Renom, P. (2011). Seasonal response of Posidonia oceanica to light disturbances. Marine Ecology Progress Series, 423, 29-38.

45. Serrano, O., Mateo, M. A., Renom, P., \& Julià, R. (2012). Characterization of soils beneath a Posidonia oceanica meadow. Geoderma, 185, 26-36.

46. Tahrani, L., Van Loco, J., Anthonissen, R., Verschaeve, L., Ben Mansour, H., \& Reyns, T. (2017). Identification and risk assessment of human and veterinary antibiotics in the wastewater treatment plants and the adjacent sea in Tunisia. Water Science and Technology, 76(11), 3000-3021.

47. Tamburini, E., Doni, L., Lussu, R., Meloni, F., Cappai, G., Carucci, A., ... \& Vitali, F. (2020). Impacts of anthropogenic pollutants on benthic prokaryotic communities in Mediterranean touristic ports. Frontiers in microbiology, 11, 1234.

48. Tarquinio, F., Hyndes, G. A., Laverock, B., Koenders, A., \& Säwström, C. (2019). The seagrass holobiont: understanding seagrass-bacteria interactions and their role in seagrass ecosystem functioning. FEMS microbiology letters, 366(6), fnz057.

49. Torta, L., Lo Piccolo, S., Piazza, G., Burruano, S., Colombo, P., Ottonello, D., ... \& Calvo, S. (2015). Lulwoana sp., a dark septate endophyte in roots of Posidonia oceanica (L.) Delile seagrass. Plant biology, 17(2), 505-511.

50. Tovar-Sánchez, A., Serón, J., Marbà, N., Arrieta, J. M., \& Duarte, C. M. (2010). Long-term records of trace metal content of western Mediterranean seagrass (Posidonia oceanica) meadows: Natural and anthropogenic contributions. Journal of Geophysical Research: Biogeosciences, 115(G2).

51. Vohník, M., Borovec, O., Župan, I., Vondrášek, D., Petrtýl, M., \& Sudová, R. (2015). Anatomically and morphologically unique dark septate endophytic association in the roots of the Mediterranean endemic seagrass Posidonia oceanica. Mycorrhiza, 25(8), 663-672.

52. Wahjono, H., Radjasa, O. K., Sabdono, A., Khoeri, M. M., \& Karyana, E. (2015). Antimycobacterial Activities from Seagrass Enhalus sp. Associated Bacteria Against Multi Drug Resistance Tuberculosis (MDR TB) Bacteria. Procedia Environmental Sciences, 23, 253-259.

53. Yoshida, A., Seo, Y., Suzuki, S., Nishino, T., Kobayashi, T., Hamada-Sato, N., ... \& Imada, C. (2008). Actinomycetal community structures in seawater and freshwater examined by DGGE analysis of 16S rRNA gene fragments. Marine Biotechnology, 10(5), 554-563.

\section{Tables}

Table 1. Antibiotics and concentrations used in this study.

\begin{tabular}{|c|c|c|c|c|c|c|c|}
\hline Class & Abbreviation & Antibiotic & Amount & Class & Abbreviation & Antibiotic & Amount \\
\hline \multirow[t]{4}{*}{$\beta$-lactams } & CTX & Cefotaxime & $30 \mu \mathrm{g}$ & Carbapenems & $\mathrm{IMI}$ & Imipenem & $10 \mu \mathrm{g}$ \\
\hline & $A$ & Amoxicillin & $25 \mu \mathrm{g}$ & Phenicol & C & Chloramphenicol & $10 \mu \mathrm{g}$ \\
\hline & ATM & Aztreonam & $30 \mu \mathrm{g}$ & Aminoglycosides & AK & Amikacin & $30 \mu \mathrm{g}$ \\
\hline & CAZ & Ceftazidime & $30 \mu \mathrm{g}$ & Macrolide & ATH & Azithromycin & $15 \mu \mathrm{g}$ \\
\hline Tetracyclines & $\mathrm{T}$ & Tetracycline & $30 \mu \mathrm{g}$ & Sulphonamides & TM & Trimethoprim & $5 \mu \mathrm{g}$ \\
\hline Quinolones & CIP & Ciprofloxacin & $5 \mu \mathrm{g}$ & Rifamycin & $\mathrm{RP}$ & Rifampicin & $5 \mu \mathrm{g}$ \\
\hline
\end{tabular}

Table 2. Colony forming units (CFU) of cultivable bacteria per gram of Posidonia oceanica seagrass (Leaves and Epiphytes) in culture media. 


\begin{tabular}{|llllll|}
\hline Sites & $\begin{array}{l}\text { S1 } \\
\text { (Mahdia) }\end{array}$ & $\begin{array}{l}\text { S2 } \\
\text { (Rejiche) }\end{array}$ & $\begin{array}{l}\text { S3 } \\
\text { (Salakta) }\end{array}$ & $\begin{array}{l}\text { S4 } \\
\text { (Chebba) }\end{array}$ & $\begin{array}{l}\text { S5 } \\
\text { (Melloulech) }\end{array}$ \\
\hline Leaves (CFU/g) & $5.2510^{9}$ & $2.3210^{10}$ & $3.7210^{9}$ & $5.1410^{9}$ & $9.1410^{7}$ \\
\hline Epiphytes (CFU/g) & $2.7910^{9}$ & $2.7010^{10}$ & $5.9510^{9}$ & $4.0310^{7}$ & $5.2710^{8}$ \\
\hline
\end{tabular}

Table 3. Identification of selected multidrug-resistant endophytic strains isolated from Posidonia oceanica seagrass.

\begin{tabular}{|c|c|c|c|c|c|c|c|}
\hline Isolates & $\begin{array}{l}\text { ITS } \\
\text { haplotype }\end{array}$ & $\begin{array}{l}\text { Accession } \\
\text { number }\end{array}$ & $\begin{array}{l}\text { Closest relative/ Accession } \\
\text { number }\end{array}$ & $\begin{array}{l}\text { Length } \\
\text { (bp) }\end{array}$ & $\begin{array}{l}\text { Sequence } \\
\text { similarity } \\
(\%)\end{array}$ & $\begin{array}{l}\text { Affiliation / } \\
\text { Families }\end{array}$ & $\begin{array}{l}\text { Phenotype } \\
\text { of antibiotic } \\
\text { resistance }\end{array}$ \\
\hline S1-L1 & $\mathrm{H} 1$ & MZ350537 & $\begin{array}{l}\text { Bacillus paranthracis / } \\
\text { NR_157728.1 }\end{array}$ & 824 & 100 & \multirow[t]{7}{*}{$\begin{array}{l}\text { Firmicute / } \\
\text { Bacillaceae }\end{array}$} & $\begin{array}{l}\text { CTX, ATM, } \\
\text { TM, RP, A, C, } \\
\text { CAZ }\end{array}$ \\
\hline S2-E2 & H3 & MZ350538 & $\begin{array}{l}\text { Bacillus } \\
\text { wiedmannii / NR_152692.1 }\end{array}$ & 728 & 98 & & $\begin{array}{l}\text { CTX, ATM, } \\
\text { TM, RP, A, C, } \\
\text { CAZ }\end{array}$ \\
\hline S3-E1 & $\mathrm{H} 2$ & MZ350539 & $\begin{array}{l}\text { Bacillus wiedmannii } \\
\text { /NR_152692.1 }\end{array}$ & 775 & 99 & & $\begin{array}{l}\text { CTX, ATM, } \\
\text { TM, RP, A, C, } \\
\text { CAZ }\end{array}$ \\
\hline S3-E2 & $\mathrm{H} 4$ & MZ350540 & $\begin{array}{l}\text { Bacillus } \\
\text { oceanisediminis / NR_117285.1 }\end{array}$ & 680 & 98 & & $\begin{array}{l}\text { CTX, ATM, } \\
\text { TM, RP, A, } \\
\text { CAZ }\end{array}$ \\
\hline S3-L3 & $\mathrm{H} 3$ & MZ350541 & $\begin{array}{l}\text { Bacillus wiedmannii } \\
\text { / NR_152692.1 }\end{array}$ & 805 & 99 & & $\begin{array}{l}\text { CTX, ATM, } \\
\text { TM, RP, A, } \\
\text { CAZ }\end{array}$ \\
\hline S4-L7 & $\mathrm{H} 4$ & MZ350542 & Bacillus firmus / NR_112635.1 & 824 & 99 & & $\begin{array}{l}\text { ATM, ATH, } \\
\text { TM, RP, A, C, } \\
\text { CAZ }\end{array}$ \\
\hline S5-L13 & $\mathrm{H} 2$ & MZ350543 & $\begin{array}{l}\text { Bacillus } \\
\text { paramycoides / NR_157734.1 }\end{array}$ & 761 & 99 & & $\begin{array}{l}\text { CTX, ATM, } \\
\text { CIP, TM, RP, } \\
\text { A, C, CAZ }\end{array}$ \\
\hline
\end{tabular}

\section{Figures}

Figure 1

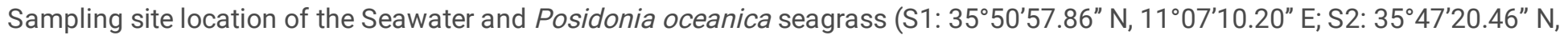

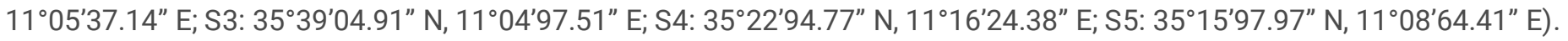

Figure 2 
Denaturing gradient gel electrophoresis (DGGE) gel profiles from triplicate of five seawater samples showing the bacterial community structure based on the variable region V3-V5 of $16 \mathrm{~S}$ rRNA. Urea and formamide gradient ranged from $40 \%$ to $60 \%$. Three kinds of bands were distinct with correlation to the running level, as short (A), medium (B) and long migration bands (C). Species richness index $(R)$ and Simpson diversity index (D) were indicated in the lower part of the gel.

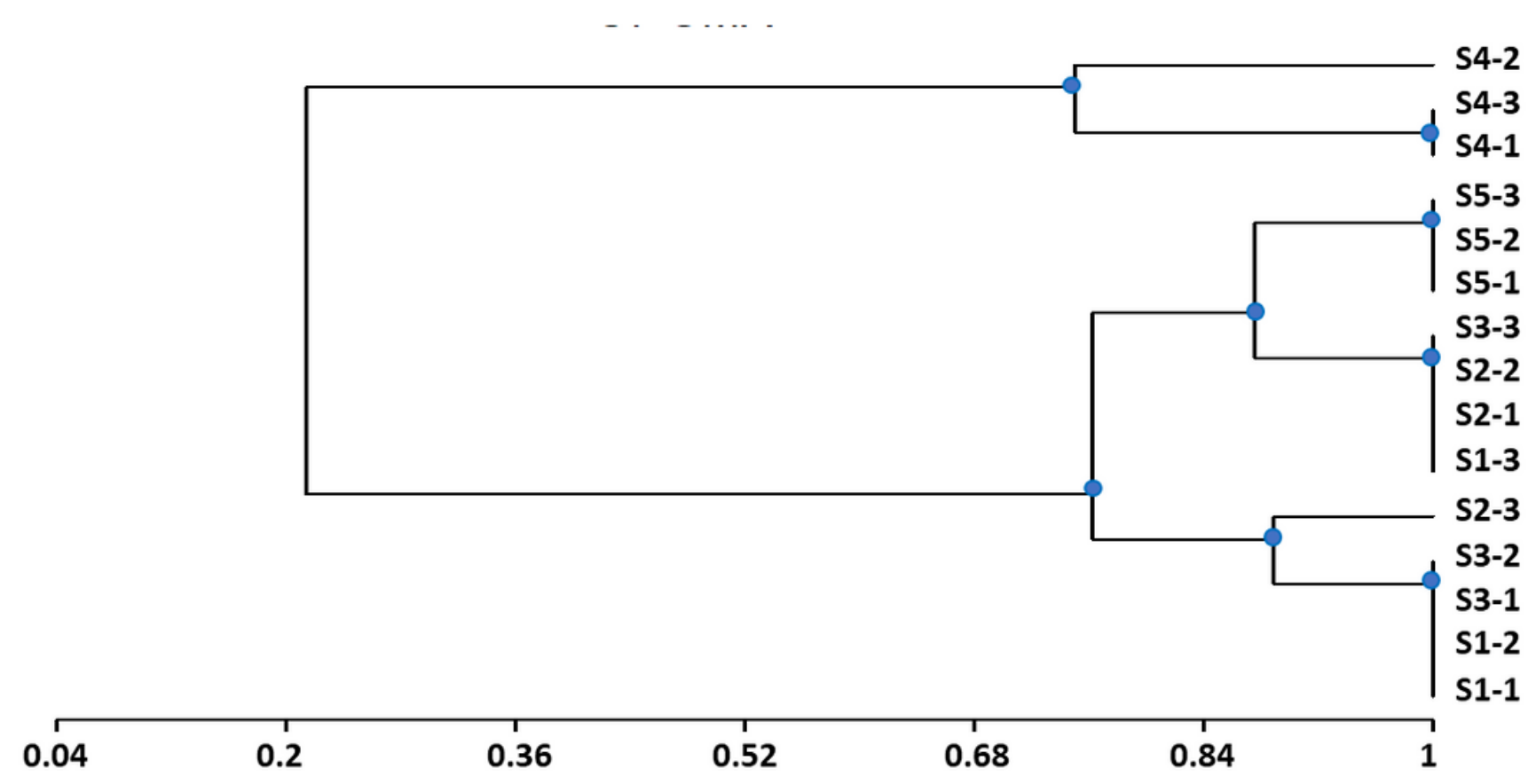

\section{Figure 3}

Clustering of DGGE patterns by software analysis using the Jaccard's coefficient with the UPGMA algorithm. 


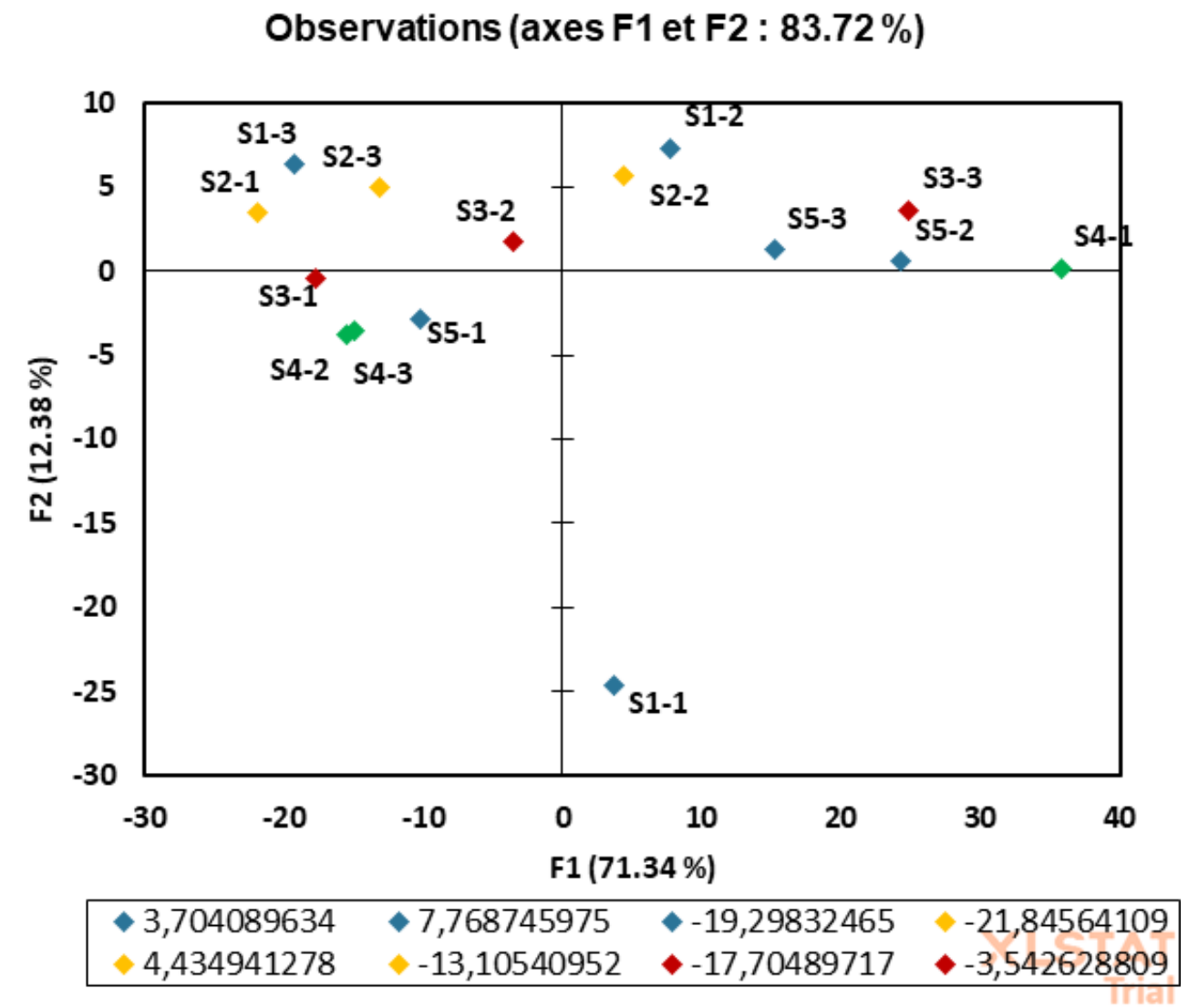

\section{Figure 4}

Principal component analysis (PCA) generated from the DGGE profiles of bacterial communities in the coastal seawater samples.

Figure 5

Histogram of the 43 endophytic bacterial isolates resistance to 12 antibiotics. The number indicates the percentage of resistant isolates for each antibiotic.

Figure 6

ITS-PCR fingerprinting patterns of seven multidrug-resistant endophytic bacterial isolates resolved by agarose gel electrophoresis. Haplotypes: H1- H4, M: molecular size marker 100 pb, isolates: S1-L1; S3-E1; S3-L3; S5-L13; S2-E2; S3-E2; S4-L7.

Figure 7

Phylogenetic tree of seven partial 16S rRNA sequences of multidrug-resistant endophytic strains isolated from Posidonia oceanica seagrass. Bootstrap values obtained with 1000 repetitions were indicated as percentages at all branches. GenBank accession numbers are given in parentheses. Staphylococcus arlettae (NR_024664.1) was chosen as the out-group to root the tree. 